\title{
Biofouling in capillary and spiral wound membranes facilitated by marine algal bloom
}

\author{
L.O. Villacorte ${ }^{a, b, c, *}$, Y. Ekowati ${ }^{a}$, H.N. Calix-Ponce ${ }^{a}$, V. Kisielius ${ }^{b}$, J.M. Kleijn ${ }^{d}$, J.S. Vrouwenvelder ${ }^{e, f}$, J.C. \\ Schippers ${ }^{a}$ and M.D. Kennedy $y^{a, g, *}$
}

${ }^{a}$ Department of Environmental Engineering and Water Technology, IHE Delft Institute for Water Education, Westvest 7, 2611 AX Delft, Netherlands

${ }^{b}$ Wetsus, European Centre of Excellence for Sustainable Water Technology, Oostergoweg 9, 8911 MA Leeuwarden, The Netherlands

${ }^{\mathrm{c}}$ Grundfos Holding A/S, Poul Due Jensens Vej 7, 8850 Bjerringbro, Denmark

d Physical Chemistry and Soft Matter, Wageningen University, Stippeneng 4, 6708WE Wageningen, Netherlands

e Department of Biotechnology, Faculty of Applied Sciences, Delft University of Technology, Van der Maasweg 9, 2629 HZ Delft, The Netherlands

${ }^{f}$ King Abdullah University of Science and Technology (KAUST), Water Desalination and Reuse Center (WDRC), Division of Biological and Environmental Science and Engineering (BESE), Thuwal 23955-6900, Saudi Arabia.

${ }^{g}$ Faculty of Civil Engineering and Geosciences, Delft University of Technology, Stevinweg 1, 2628 CN Delft, Netherlands

* Corresponding authors. L.O. Villacorte: Grundfos Holding A/S Denmark (current affiliation), Ivillacorte@grundfos.com; M.D. Kennedy: m.kennedy@un-ihe.org 


\section{Abstract}

Algal-derived organic matter (AOM), particularly transparent exopolymer particles, has been suspected to facilitate biofilm development in membrane systems (e.g., seawater reverse osmosis). This study demonstrates the possible role of AOM on biofouling in membrane systems affected by marine algal blooms. The tendency of AOM from bloom-forming marine algae to adhere to membranes and its ability to enhance biofilm growth were measured using atomic force microscopy, flow cytometry, liquid chromatography and accelerated membrane biofouling experiments. Adhesion force measurements indicate that AOM tends to adhere to clean membranes and even more strongly to AOM-fouled membranes. Batch growth tests illustrate that the capacity of seawater to support bacterial growth can significantly increase with AOM concentration. Biofouling experiments with spiral wound and capillary membranes illustrate that when nutrients availability are not limited in the feed water, a high concentration of AOM - whether in suspension or attached to the membrane - can substantially accelerates biofouling. A significantly lower biofouling rate was observed on membranes exposed to feed water spiked only with AOM or easily biodegradable nutrients. The abovementioned findings indicate that AOM facilitates the onset of membrane biofouling primarily as a conditioning platform and to some extent as a nutrient source for biofilm-forming bacteria.

Keywords: Biological fouling; seawater reverse osmosis; capillary and spiral wound membranes, transparent exopolymer particles (TEP); algal organic matter. 


\section{Introduction}

The growth and accumulation of biological matter on reverse osmosis (RO) membranes is a major operational challenge in membrane-based desalination plants (Flemming et al.,1997; Baker and Dudley, 1998; Vrouwenvelder et al., 1998; Nguyen et al., 2012). This phenomenon adversely impact the RO performance due to increased required driving pressure to compensate for the reduction of membrane permeability and higher head loss across spacers or membrane bundles as well as declining product water quality due to increased salt passage through the membrane. Recovering the reduced system performance would further increase operational cost due to frequent chemical cleanings and replacement of damaged or irreversibly fouled membranes. Prolonged system downtime during chemical cleaning or membrane replacement also translates to reduced water production capacity of the desalination plant.

The processes leading to biofouling in RO membranes can be described in four phases, namely: (1) surface conditioning, (2) bacterial adhesion and colonization, (3) biofilm formation and (4) biofouling (Flemming and Schaule, 1998). Initially, organic macromolecules adsorb on the surface of a clean membrane eventually leading to the formation of a "conditioning film". These fast adsorbing organic substances are mainly anionic biopolymers, which tends to increase the capacity of the surface to absorb and concentrate nutrients from the feed water of the RO membrane (Winters et al., 1983; Marshall, 1996). Fast adhering bacteria from the feed water first colonise the "conditioned surfaces" and eventually form micro-colonies. Bacterial communities that produce a relatively large amount of extracellular polymeric substances (EPS) are most likely to be the primary colonisers (Allison and Sutherland, 1987; Winters and Isquith, 1979). Further growth of primary colonizers and subsequent adhesion of more species of bacteria may lead to a rapid increase in bacterial colonies and accumulation of excreted EPS, eventually forming a layer of slime known as "biofilm" (Characklis, 1981). When biofilm thickness or its hydraulic resistance increase over 
time and surpass the operationally defined "level of interference" on the RO system, such phase is considered as biofouling (Flemming, 2002). In practice, such "level of interference" is often defined as $\geq 10 \%$ decrease in normalized flux, $\geq 10 \%$ increase in feed channel pressure drop, and/or $\geq 5 \%$ increase in salt passage (Dow W\&PS, 2011; Hydranautics, 2014). Chemical cleaning-in-place (CIP) is typically recommended when at least one of these criteria is exceeded.

In surface water, natural organic substances that can potentially foul RO typically comprise biopolymers from phyto- and bacterio-planktons (Amy, 2008; Jeong et al., 2013). This pool of organic substances may be colonized, degraded or utilized as nutrients to support growth of bacteria and biofilm formation in RO membranes. Back in the eighties, Winters et al. (1983) suspected that Alcian Blue stainable substances in seawater are mainly involved in the surface conditioning of RO membranes. Alcian Blue is a cationic dye known for its specific affinity to acidic polysaccharides and glycoproteins (Ramus, 1977). A decade later, Alldredge et al. (1993) developed the first technique to quantify Alcian Blue stainable substances in seawater which they operationally defined as transparent exopolymer particles (TEP). It took another decade before TEPs were eventually implicated as "major initiators" of biofilm in RO membranes (Berman and Holenberg, 2005). This then paved the way for various investigations related to the impact of these substances in membrane-based water treatment systems (e.g., dela Torre et al., 2008; Bar-Zeev et al., 2009; Kennedy et al., 2009; Villacorte et al., 2009; Berman et al., 2011; van Nevel et al., 2012; Discart et al., 2013).

Bar-Zeev et al., $(2012,2015)$ proposed a "revised paradigm of aquatic biofilm formation facilitated by TEPs" where they emphasize the important role of TEPs in the conditioning and bacterial colonization of surfaces exposed to surface water. In seawater, TEPs tend to have a highly adhesive surface, with reported stickiness of about 2-4 orders of magnitude higher than other suspended particles (Passow, 
2002). These gel-like substances are often associated with or tend to absorb proteins, lipids, trace elements and heavy metals from the water (Passow, 2002), making them a nutritious platform and a hotspot for bacterial activity (Alldredge et al., 1993; Passow and Alldredge, 1994).

The abundance of TEPs in seawater is generally associated with the occurrence of algal blooms as they are a major component of substances produced by phytoplankton, commonly known as algal organic matter (AOM; Villacorte et al., 2015a; Passow, 2002). In seawater RO desalination plants, granular media filters (GMF) are usually installed to pretreat seawater prior to the RO system. During algal blooms, GMF - in combination with inline coagulation - is expected to reduce the concentration of algal cells and AOM in the RO feedwater. However, a substantial breakthrough of these material in GMF is still likely to occur due to its relatively large pores (typically $150 \mu \mathrm{m}$ ). This can rapidly cause organic fouling and eventually enhance biofouling in the downstream RO membranes. Currently, pretreatment with microfiltration (MF) or ultrafiltration (UF) is increasingly used as an alternative for GMF because it is expected to be more effective in terms of algae and AOM removal during severe blooms (Villacorte et al., 2015b). Nevertheless, complete removal of AOM has not been achieved with the current MF/UF membranes (Villacorte et al., 2015c). A better understanding of the impact of AOM on membrane biofouling is therefore important to support development of effective pretreatment and cleaning strategies for membrane-based desalination plants impacted by algal blooms.

The effect of AOM in the feed water on the operation of capillary/tubular UF membranes (Villacorte et al., 2010; Berman et al., 2011; Schurer et al., 2013; Discart et al., 2013) and polyamide thin film composite membranes (Her et al., 2004; Valladares Linares et al., 2012; Lee et al., 2015; Li et al. 2016) have already been demonstrated in previous studies. However, these studies mainly focused on the short-term direct effect of AOM on membrane fouling (organic or particulate fouling) rather than their 
role in biofouling development. The present study aims to elucidate the impact of AOM on the various processes leading to biofouling in capillary and spiral wound membranes. This was implemented using advanced analytical techniques including atomic force microscopy, flow cytometry and liquid chromatography, and further illustrated through accelerated membrane biofouling experiments. 


\section{Materials and methods}

\subsection{Extraction of algal organic matter}

A strain (CCAP 1010/27) of a common species of bloom-forming marine alga, Chaetoceros affinis, was inoculated in a batch culture with sterilized f/2+Si medium (Guillard, 1975) in artificial seawater (ASW). The procedure of preparing the ASW and maintaining the culture are described in our previous works (Villacorte, 2014; Villacorte et al., 2015d). The culture was maintained until it reached the stationary phase and then the AOM solution was extracted by sedimentation and filtration as described by Villacorte et al. (2013). The algal culture was not totally axenic which means that bacteria were present in the AOM solution. It should be noted, however, that bacteria are always present during algal blooms in natural waters.

\subsection{Liquid chromatography - organic carbon detection (LC-OCD)}

Selected water samples collected from the growth potential tests were analyzed using LC-OCD technique as described by Huber et al. (2011). LC-OCD analysis fractionates the constituents of organic materials in terms of biopolymers, humic substances, building blocks, low molecular weight (LMW) organic acids and organic neutrals. Typically, LC-OCD analysis is performed after pre-filtering the sample through $0.45 \mu \mathrm{m}$ filters. For this study, LC-OCD were performed without pre-filtration and water samples were directly fed through a series of two chromatogram columns (HW65S and HW50S). The theoretical maximum chromatographable size without sample pre-filtration was $2 \mu \mathrm{m}$ (Huber, 2012). 


\subsection{Atomic force microscopy}

Force measurements using an atomic force microscope (AFM) have been performed in various studies to determine the affinity of model foulants to membrane surfaces (Frank and Belfort, 2003; Li and Elimelech, 2004; Yamamura et al., 2008). In the present study, the adhesive strength of AOM was determined by measuring the interactions between a polystyrene microsphere coated with AOM and clean or AOM-fouled membranes in ASW solution. The adhesion force and energy were established following the protocol described by Villacorte et al. (2015e). Briefly, AFM cantilevers with attached polystyrene (PS) microspheres with a diameter of $25 \mu \mathrm{m}$ (Novascan Technologies, USA) were submerged in a petri-dish filled with $\mathrm{AOM}$ solution $(\sim 5 \mathrm{mg} \mathrm{C} / \mathrm{L})$ for 5 days at $4{ }^{\circ} \mathrm{C}$ to allow adsorption of $\mathrm{AOM}$. The surfaces of clean capillary and spiral wound membrane were represented by a flat sheet polyethersulfone UF membrane (Omega 100 kDa MWCO, Pall Corp.) and a polyamide thin-film composite RO membrane (Filmtec BW30, Dow), respectively. Before the experiment, the UF membrane was cleaned by soaking in ultra-pure water for 24 hours and then filtering through $>10 \mathrm{ml}$ ultrapure water. Coupons $(\sim 1 \mathrm{~cm} \times 10 \mathrm{~cm})$ of polyamide RO membranes were stored in $1 \%$ sodium bisulphite solution for at least 24 hours and then rinsed with ultra-pure water before the experiment. An AOMfouled membrane surface was represented by a UF membrane fouled by filtering through $5 \mathrm{ml}$ of AOM solution at $60 \mathrm{~L} / \mathrm{m}^{2} / \mathrm{h}$ flux.

Force measurements were performed at room temperature $\left(\sim 20^{\circ} \mathrm{C}\right)$ using a ForceRobot 300 (JPK Instruments) provided with a small volume liquid cell filled with ASW solution. The cantilevers' sensitivity and spring constant were calibrated using the ForceRobot program. In principle, as the AFM cantilever with PS microsphere is moved towards or retracted from the membrane surface, the AFM cantilever deflects depending on the direction and magnitude of the forces between the two surfaces. Interaction force curves as a function of the separation distance between the tip and the membrane 
surface are then generated based on Hooke's law. Each force measurement cycle generates two forcedistance (F-D) curves: the approach force curve and the retract force curve. The approach force curve shows the force interactions between the AOM coated microsphere probe and the membrane surface at different separation distances. The retract force curve exhibits the adhesion force which wis keeping the probe surface and the membrane surface together after contact. The adhesion force is identified as the maximum negative force recorded in the retract curve. Furthermore, the total energy needed to completely separate the two surfaces from contact was calculated by integrating the measured negative forces over the separation distance in the retract curve. For this study, the average force and energy values were calculated based on at least 18 force-distance curves generated at 6 different surface locations of the membrane sample.

\subsection{Marine bacteria}

A common species of marine bacteria, Vibrio harveyi was used as model seawater bacteria. This species has been used as a standard bacterium for measuring assimilable organic carbon (AOC) in seawater (Weinrich et al., 2011). A pure strain of the bacteria (NCCB 79042) was inoculated in sterilised saline (34 $\mathrm{g} / \mathrm{L}$ ) medium for lucibacterium and incubated at $30^{\circ} \mathrm{C}$ until the concentration reach $\sim 100$ million cells/ml. The solution was then diluted 100 times with ASW for the biofouling experiments. Cell concentration was measured based on the number of colonies grown and incubated at $37^{\circ} \mathrm{C}$ on peptone agar media for 24-48 hours.

\subsection{Bacterial growth potential test}

The AOM solution used in the growth potential test was pre-filtered through $0.2 \mu \mathrm{m}$ polycarbonate membranes (Whatman Nuclepore) to remove bacteria which may be present in the batch culture. To remove low molecular weight constituents and residual medium nutrients from the solution, the filtered 
solution was then dialyzed against ultra-pure water dialysate (replenished twice a day) for 3 days inside a $3.5 \mathrm{kDa}$ MWCO regenerated cellulose membrane sack (Spectra/Por 3, SpectrumLabs). LC-OCD analysis was performed on the dialyzed AOM solution to measure the final biopolymer concentration (see Section 2.2).

To prepare the batch solutions, seawater samples were collected at the intake of an RO plant in Jacobahaven, the Netherlands (North Sea Coast). The bacterial concentration of the raw seawater was measured using the flow cytometric technique described in the Swiss guideline for drinking water analysis (SLMB, 2012; Prest et al., 2013). A portion of the collected seawater sample was filtered through a $0.2 \mu \mathrm{m}$ polycarbonate filter by vacuum filtration to remove bacteria. Eight AOC-free bottles, cleaned by following the protocol of Hammes and Egli (2005), were filled with $730 \mathrm{ml}$ of filtered seawater. Different volumes of dialysed AOM solutions and sterilized ASW ( $34 \mathrm{~g} / \mathrm{L}$ ) were added to the bottles to make up $800 \mathrm{ml}$ solutions with different concentrations of $\mathrm{AOM}(0,0.08,0.4$ and $0.8 \mathrm{mgC} / \mathrm{L})$ in duplicates. A consortium of seawater bacteria was inoculated by adding $8 \mathrm{ml}$ of raw seawater ( 1 million cells $/ \mathrm{ml}$ ) to the different solutions for an initial concentration of $\sim 10,000$ cells $/ \mathrm{ml}$. The sample bottles were securely covered with caps and incubated at room temperature $\left(20 \pm 2{ }^{\circ} \mathrm{C}\right)$. The concentration of bacteria was monitored in all bottles for several days. For each bottle, the net growth was calculated by deducting the maximum cell count during the incubation period with the initial cell count. To monitor changes in concentration and composition of organic matter, LC-OCD analyses were performed for water samples collected from the bottle containing $0.8 \mathrm{mg} \mathrm{C} / \mathrm{L}$ at the beginning (day 0 ) and the $4^{\text {th }}$ day of the bacterial growth potential test. 


\subsection{Cross-flow capillary membrane set-up}

Biofouling experiments were performed using a lab-scale capillary membrane system operated in crossflow and inside-out filtration mode (Figure 1). The capillary membrane has an internal diameter of 0.8 $\mathrm{mm}$ which is consistent with the typical channel height of a spiral wound RO membrane. The membrane used was a tight polyethersulfone UF membrane ( $7 \mathrm{kDa} \mathrm{MWCO})$ to allow retention of most biopolymers on the membrane surface (Villacorte et al., 2013). The setup comprises a membrane module (1 m effective length) fabricated by inserting two capillary membranes into $8 \mathrm{~mm}$ diameter polyethylene tube. Both ends of the tubing (except the capillary ends) were sealed with water-proofing resin. A permeate outlet was positioned in the middle of the module to allow inside-out filtration. The filtration system was equipped with a multi-channel peristaltic pump (Masterflex L/S 77201-60) to provide consistent feed flow to multiple modules and pressure sensors (Endress+Hauser PMD70) to record pressure drop and concentrate pressure. A digital balance (Sartorius TE3102S) was employed to measure permeate flow. The cross-flow velocity (CFV) and permeate flux (J) were set to the required values by adjusting the speed of the feed pump and manually regulating the valve on the concentrate side. Since the CFV and J can gradually change over time, re-adjusting them back to the initial flow settings were performed for at least twice a day. All the tests were performed at room temperature $\left(20 \pm 2{ }^{\circ} \mathrm{C}\right)$, flux of $15 \mathrm{~L} / \mathrm{m}^{2} . \mathrm{h}$ and cross-flow velocity of $0.15 \mathrm{~m} / \mathrm{s}$. Under this condition, the capillary membranes showed an average clean water resistance of $7.9 \times 10^{12}( \pm 15 \%) \mathrm{m}^{-1}$ and feed channel pressure drop of $78 \mathrm{mbar}( \pm 5 \%)$. The membrane resistance of low molecular weight cut-off UF was about 5-7 times higher than in most commercial UF membranes (100-300 kDa). 


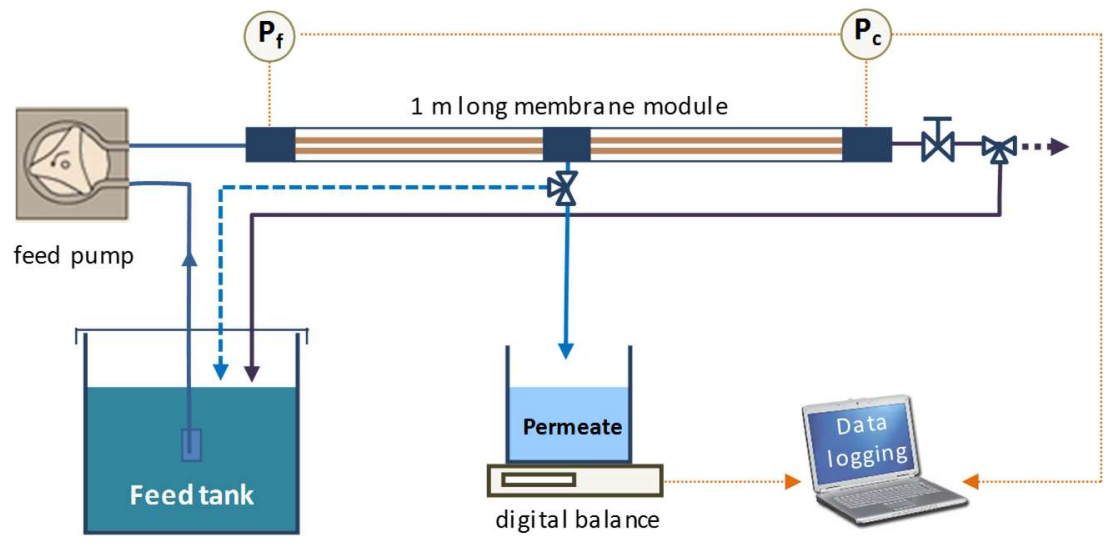

Figure 1. Cross-flow filtration set-up with capillary membranes.

\subsection{Membrane fouling simulator}

Biofouling experiments were also performed using membrane fouling simulators (MFS) to mimic biofouling in spacer-filled RO membrane channels. The principle and design specifications of the MFS flow cell are described by Vrouwenvelder et al. (2006). The MFS set-up used in this study is presented in Figure 2. A multi-channel peristaltic pump (Masterflex L/S 77201-60) was used to provide constant feed water flow to multiple MFS flow cells from and back to the feed tanks. The feed tanks were elevated 0.6 $m$ above the MFS cells to minimize bubble formation in the cells that may interfere in the biofilm accumulation and pressure drop readings. To measure the pressure drop through the MFS cell, differential pressure sensor (Endress+Hauser PMD75) was installed. The MFS flow cells were fitted with Trisep TS80 spiral wound RO membranes coupons $(4 \mathrm{~cm} \times 20 \mathrm{~cm}$ ) and feed spacers (Vrouwenvelder et al., 2009). Before the experiments, the coupons were stored in $1 \%$ sodium bisulphite solution for at least 24 hours and then rinsed with ultra-pure water. Feed channel pressure drop readings were recorded over time. Before each recording, the linear cross-flow velocity across the MFS cell was verified and the feed flow was adjusted when necessary. 


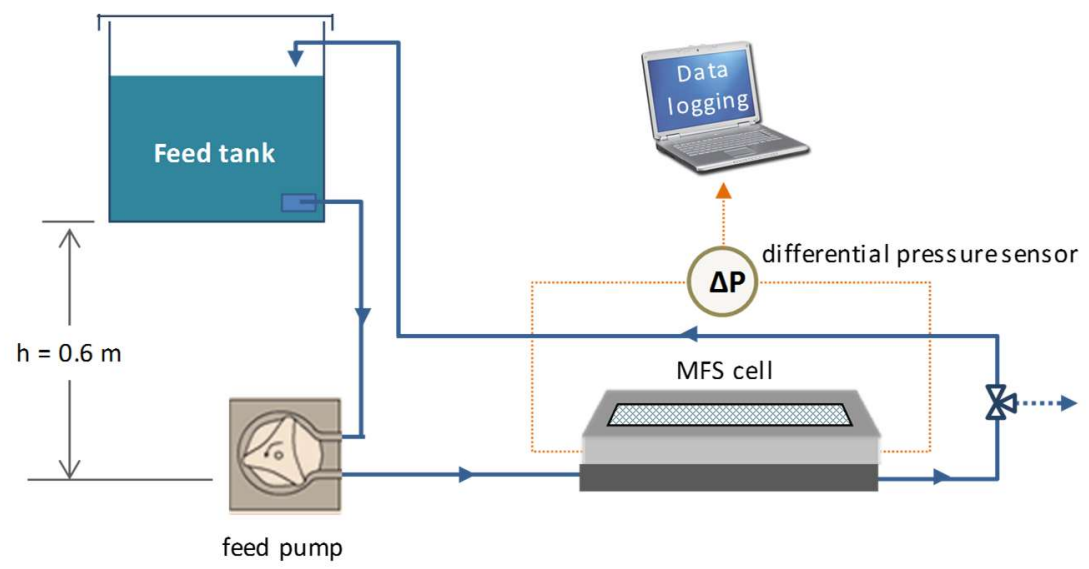

Figure 2. Membrane fouling simulator set-up with spiral wound membrane.

\subsection{Biofouling experiments}

Three sets of tests were conducted to investigate the effect of (1) AOM spiked in the feed water of the capillary membrane, (2) AOM as a conditioning layer on the surface of the capillary membrane and (3) AOM as a conditioning layer on the surface of the spiral wound membrane. Tests 1 and 2 were performed with the cross-flow UF set-up while Test 3 was performed with the MFS set-up. Each set of tests was performed with 2 or 4 identical units operating in parallel and identical flow settings. Both the concentrate and permeate were recycled back to the feed tank in all tests. Unless otherwise specified, CNP nutrients $(0.2 \mathrm{mgC} / \mathrm{L}, 0.04 \mathrm{mg} \mathrm{N} / \mathrm{L}, 0.01 \mathrm{mg} \mathrm{P} / \mathrm{L})$ were added intermittently to the feed water to accelerate biological growth on the membranes and to ensure the feed water is not nutrient limited (Araújo et al., 2012). To mimic bacterial growth in seawater, an untreated natural seawater (NSW) sample from an RO plant ( $10 \%$ of total feed volume) or a common marine bacterium $V$. harveyi ( 1 million cells $/ \mathrm{ml}$ ) was introduced to the feed solution at the beginning or after the conditioning phase of the experiments. Table 1 describes the test conditions. 
Table 1. Experimental conditions implemented to investigate the role of AOM on biofouling development in capillary and spiral wound membranes.

\begin{tabular}{|c|c|c|c|c|c|c|}
\hline $\begin{array}{l}\text { Test } \\
\text { code }\end{array}$ & $\begin{array}{l}\text { Membrane } \\
\text { type }\end{array}$ & $\begin{array}{l}\text { CFV }(\mathrm{m} / \mathrm{s}) / \\
\text { Flux }\left(\mathrm{L} / \mathrm{m}^{2} \cdot \mathrm{h}\right)\end{array}$ & $\begin{array}{l}\text { Feedwater } \\
\text { composition }\end{array}$ & $\begin{array}{l}\text { Marine } \\
\text { bacteria }\end{array}$ & $\begin{array}{l}\text { Autopsy } \\
\text { on day }\end{array}$ & Remarks \\
\hline \multicolumn{7}{|c|}{ 1) Effect of AOM suspended in feed water (results in Section 3.3) } \\
\hline $\mathrm{C} 1$ & & & $\begin{array}{l}90 \%(\text { ASW, AOM) } \\
+10 \% \mathrm{NSW}\end{array}$ & & - & $\begin{array}{l}\text { Organic fouling by } \\
\text { AOM }\end{array}$ \\
\hline $\mathrm{C} 2$ & Capillary & & $\begin{array}{l}90 \%(\text { ASW, C, N, P) } \\
+10 \% \text { unfiltered NSW }\end{array}$ & $\begin{array}{l}\text { Bacterial } \\
\text { consortium }\end{array}$ & - & $\begin{array}{l}\text { Biofouling without } \\
\text { AOM }\end{array}$ \\
\hline $\mathrm{C} 3$ & $\begin{array}{c}\text { 7kDa PES } \\
\text { UF }\end{array}$ & 0.15 / 15 & $\begin{array}{l}90 \% \text { (ASW, AOM, N, P) } \\
+10 \% \text { unfiltered NSW }\end{array}$ & $\begin{array}{l}\text { from NSW } \\
\text { added at } \\
\text { Day } 0\end{array}$ & - & $\begin{array}{l}\text { AOM as carbon } \\
\text { nutrient }\end{array}$ \\
\hline $\mathrm{C} 4$ & & & $\begin{array}{l}90 \%(\text { ASW, AOM, C, N, P) } \\
+10 \% \text { unfiltered NSW }\end{array}$ & & - & $\begin{array}{l}\text { Biofouling with } \\
\text { AOM }\end{array}$ \\
\hline
\end{tabular}

2a) Effect of AOM conditioning in capillary membrane (results in Section 3.4.1)

\begin{tabular}{|c|c|c|c|c|c|c|}
\hline C5 & $\begin{array}{l}\text { Capillary } \\
7 \mathrm{kDa} \text { PES }\end{array}$ & $0.15 / 15$ & $\begin{array}{l}\text { Day 0-5: ASW, AOM } \\
\text { Day 5-7: ASW, C, N, P }\end{array}$ & $\begin{array}{l}\text { V. harveyi } \\
\text { introduced }\end{array}$ & 7 & $\begin{array}{l}\text { With AOM pre- } \\
\text { conditioning }\end{array}$ \\
\hline C6 & UF & & Day 5-7: ASW, C, N, P & on Day 5 & 7 & Reference/control \\
\hline
\end{tabular}

2b) Effect of AOM conditioning in spiral wound membrane (results in Section 3.4.2)

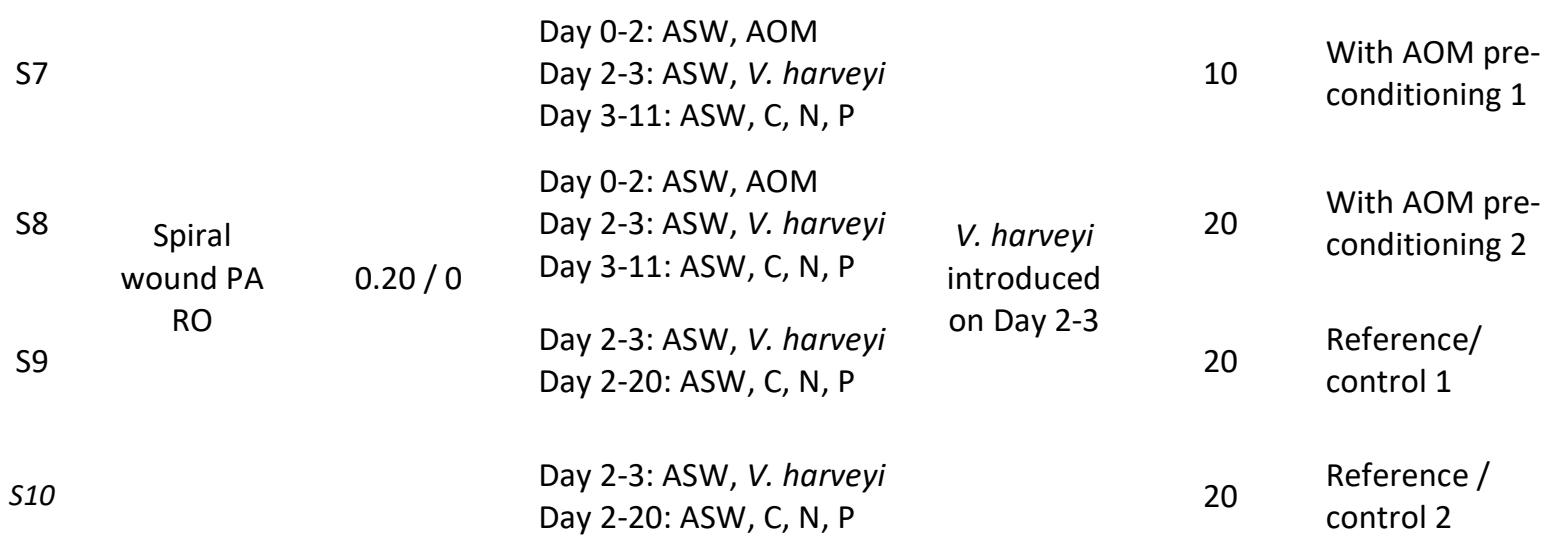

Abbreviations: $C F V=$ cross-flow velocity; $A O M=$ algal organic matter; $P E S=$ polyethersulfone; $P A=$ polyamide; $A S W=$ artificial seawater; NSW = natural seawater; $C=0.2 \mathrm{mg} \mathrm{C/L;} N=0.04 \mathrm{mg} \mathrm{N} / \mathrm{L} ; P=0.01 \mathrm{mg} P / \mathrm{L}$. 


\subsection{Membrane autopsy}

Autopsies were performed for selected experiments using the capillary set-up and MFS. For the capillary membranes, the module containing capillaries were first frozen, cut into small pieces $(3-5 \mathrm{~cm})$ and soaked in plastic cups containing $100 \mathrm{ml}$ of ultra-pure water, covered, vigorously mixed and placed in a sonicator bath (Branson 2510E-MT) for 15 mins. For spiral wound membranes, both the fouled membrane and spacers were soaked in ultrapure water and sonicated for 15 mins. Sample solutions from the sonicated membrane samples were used to measure TOC, TEP and $V$. harveyi plate counting analysis (see Section 2.4). TOC was measured using the Shimadzu $V_{\text {CPN }}$ TOC analyser. TEP measurement was based on the method by Passow and Alldredge (1995) with the latest modifications introduced by Villacorte et al. (2015e).

\subsection{Hydraulic calculations}

The water flux through a semi-permeable membrane is inversely proportional to the hydraulic resistance of the membrane. When biofilm accumulates on the surface of the membrane, additional resistance is generated. This can be explained based on the resistance in series model derived from Darcy's Law.

$J=\frac{\Delta P}{\eta\left(R_{m}+R_{c}\right)}$

Eq. 1

where $\mathrm{J}$ is the membrane permeate flux, $\Delta \mathrm{P}$ is the differential pressure between the feed and permeate side of the membrane, $\eta$ is the dynamic water viscosity, $R_{m}$ is the membrane resistance and $R_{c}$ is the gel or biofilm resistance. 
Rearranging Eq. 1 to calculate the cake resistance;

$\mathrm{R}_{\mathrm{c}}=\frac{\Delta \mathrm{P}}{\eta \mathrm{J}}-\mathrm{R}_{\mathrm{m}}$

Eq. 2

Biofilm accumulation in cross-flow membrane systems can also cause increase in the feed channel pressure drop due to partial clogging or constriction of some portions of the feed channel. The feed channel pressure drop $\left(\Delta \mathrm{P}_{\mathrm{fc}}\right)$ is measured as the difference between the recorded pressure in the feed $\left(P_{f}\right)$ inlet and concentrate $\left(P_{c}\right)$ outlet of the membrane module as shown in Eq. 3.

$\Delta \mathrm{P}_{\mathrm{fc}}=\mathrm{P}_{\mathrm{f}}-\mathrm{P}_{\mathrm{c}}$ Eq. 3 


\section{Results and discussion}

\subsection{AOM adhesion on membranes}

To evaluate the propensity of AOM to adhere to membrane surfaces, AOM to membrane and AOM to AOM interactions were measured using AFM. Figure 3 shows the force-distance curves generated from the experiments and Figure 4 shows the pull-off forces on retraction and the corresponding adhesion energies.
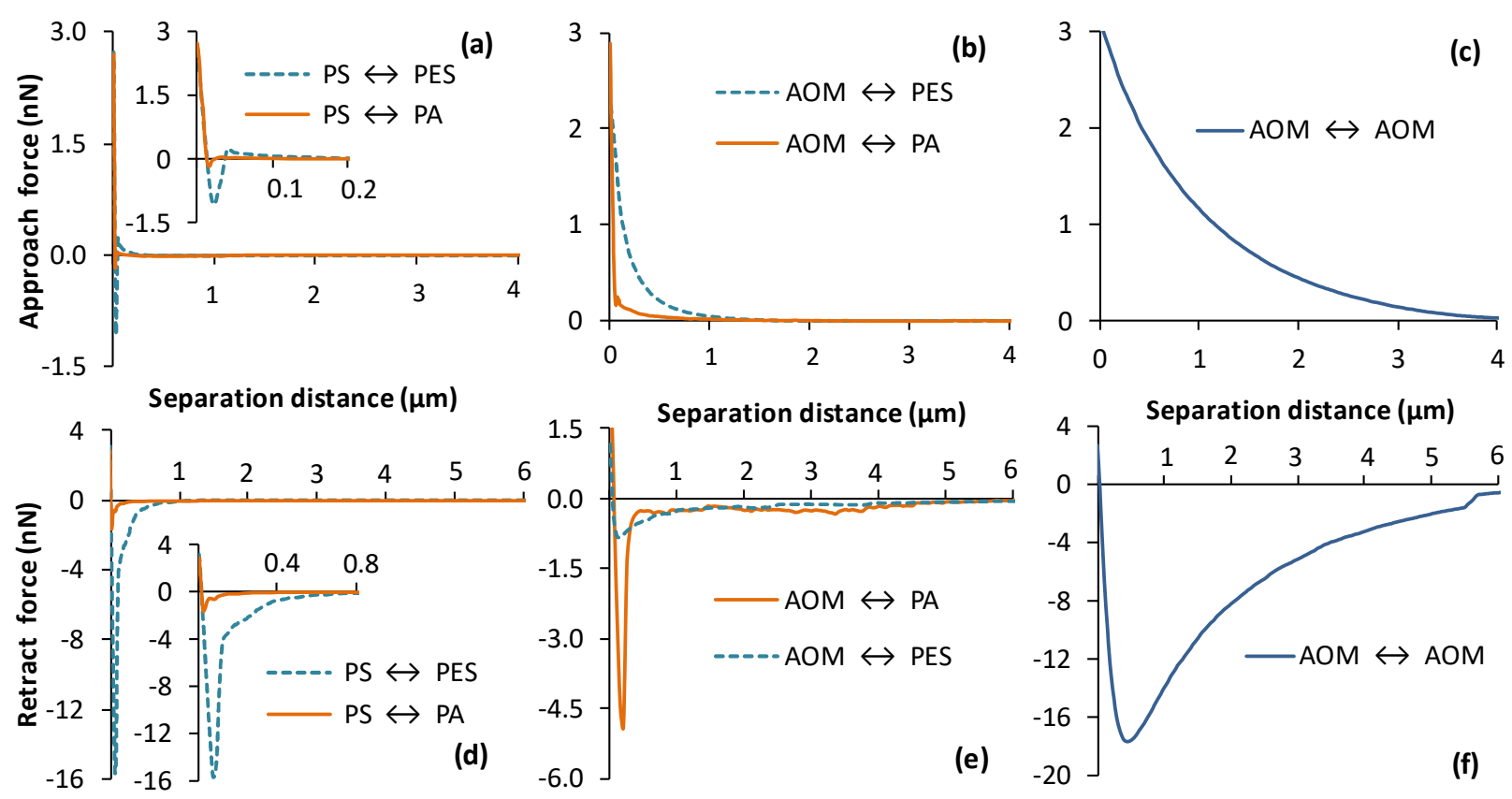

Figure 3: Characteristic force-distance curves showing interactions between different surfaces: (a-c) approach force curves; (d-f) retract force curves. AOM tends to adhere more on membrane covered with AOM than a clean one. $P S=$ clean polystyrene tip; $P E S=$ polyethersulfone membrane; $P A=$ polyamide membrane; $A O M=a l g a l$ organic matter fouled PES membrane.

The generated approach curves indicate that short-range attraction forces exist between the clean polystyrene particle and the clean membrane surfaces (Figure 3a). The attraction between clean polystyrene and clean membranes may be due to van der Waals interaction, hydrogen bonding and/or 
hydrophobic interaction. The PS particle is hydrophobic and probably prefers contact with the membrane surface over contact with water. After soaking the polystyrene probe for 5 days in AOM solution, the interaction between the probe and the membranes changed to rather long range repulsion (Figure 3b). This confirms the adsorption of AOM to the hydrophobic polystyrene microspheres after the soaking process. Both the membranes (Hurwitz et al., 2010; Ricq et al., 1997) and AOM (Henderson et al., 2008) are known to be (slightly) negatively charged. However, electrostatic repulsion may have not played a significant role in the interaction between the membranes and the AOM-coated probe. This is due to the high ionic strength in ASW solution, which screens the charges and limits the range of electrostatic interactions to distances of less than $1 \mathrm{~nm}$ (Mosley et al., 2003). The long-range (order 1 $\mu \mathrm{m})$ repulsion can therefore be attributed to the resistance exerted by the soft AOM layer as it is gradually squeezed in between the microsphere probe and the membrane surface.

The retraction curves generated after clean polystyrene particles were brought into contact with clean membranes illustrate that these particles adhere more strongly on the PES membrane than on the polyamide membrane (Figure 3d). However, when coated with AOM, the probe adheres more strongly on polyamide membranes than on PES membranes (Figure 3e). On the other hand, the adhesion between AOM-coated polystyrene particles and AOM-fouled membranes appears to be substantially stronger than the adhesion between the AOM probe and the clean membranes (Figure 3f). Moreover, adhesion was observed over a much larger distance. This shows that AOM layers can deform and stretch when pulled apart and it is only at distances of the order of several micrometers that they come apart. The softness and deformability of the biopolymer layers is also illustrated by the approach curves in Figures $3 b$ and $3 c$, showing a gradual increase in force (needed for compression of the AOM layer) over approach distances of several micrometers (1-4 $\mu \mathrm{m})$. 
Based on the average maximum retract force (Figure 4), AOM adhere on the polyamide membrane almost 5 times more strongly than on the PES membrane. However, the energies needed to detach the AOM-coated probe from the two membranes were comparable. In contrast, at least $\sim 3$ times higher force and 20 times more retraction energy was required to separate the AOM-coated probe from the AOM-fouled membrane than from the clean membranes. The strong adhesive strength of AOM on membrane surfaces can be largely attributed to hydrogen bonding, but hydrophobic interactions and chemical affinity may have contributed as well. The attachment of AOM on AOM-conditioned membrane may have been influenced by both hydrogen bonding and polymer entanglement (Flemming et al., 1997). As illustrated by the AFM results, AOM gels can be very flexible and elastic, so the disentangling process may have occurred in a stepwise fashion. Hence, it requires more energy to pull AOM off from an AOM sub-layer than from a clean surface. Since hydrogen bonding is a result of electron transfer between electronegative moieties and hydrogen atoms on AOM and membrane surfaces, the adhesion force can be influenced by the membrane surface roughness. The reported surface roughness of PA membrane is higher than PES membrane (Pieracci et al., 1999; Hurwitz et al., 2010). This might explain the higher adhesion force of AOM on PA membranes than on PES membrane because a higher surface roughness implies more contact area between the (flexible) AOM gel layer and the membrane. This is an important observation considering that for the majority of RO membranes currently applied in the field, PA is the main active layer. 


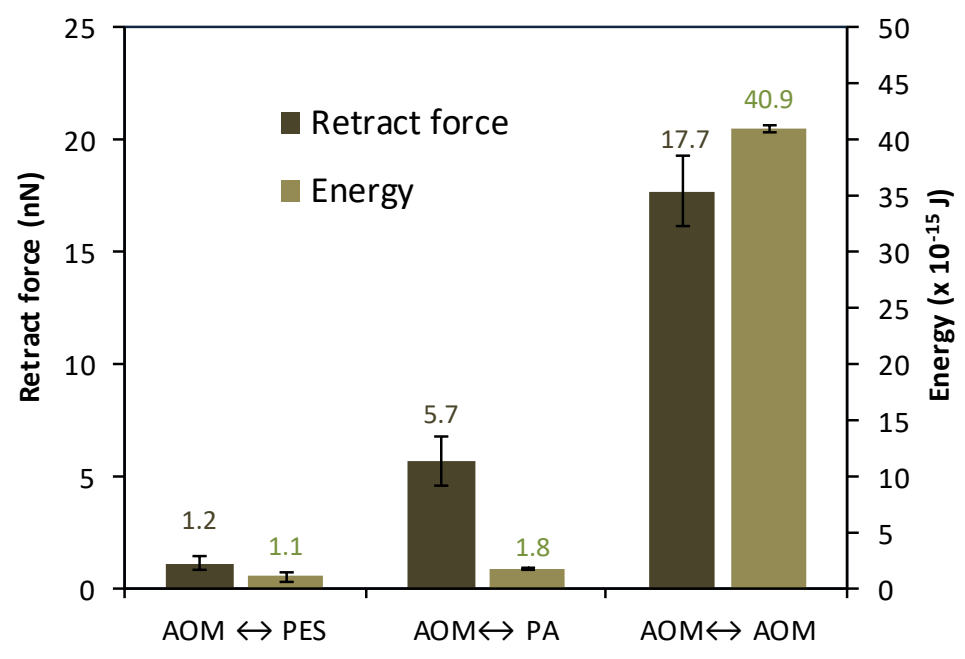

Figure 4: Comparison of average retract forces and energies between AOM-coated prove and clean or AOM-fouled membrane surfaces. The magnitude of both the retract force and energy is much higher on AOM covered membrane than on clean polyethersulfone (PES) or polyamide (PA) membrane.

Considering that the adhesion force between surfaces covered with AOM are considerably higher than between an AOM covered surface and a clean one, the accumulation rate or sticking efficiency of AOM from the feed water may eventually increase as the membrane surface is gradually covered with AOM. Moreover, marine bacterioplanktons which are typically coated with EPS, may have similar surface characteristics as an AOM specifically the biopolymer fraction (Li et al., 2015). The interaction between the AOM-coated microsphere and the AOM-coated membrane may also represent a bacterium being put into contact with a membrane with AOM conditioning. As such, the conditioning AOM layer on the membrane may not only accelerate further attachment of bacteria from the feed water but also protects them from being detached.

\subsection{Effect of AOM on bacterial growth}

The net growth of marine bacteria in water samples containing different concentrations of AOM was investigated to establish if an increase in AOM concentration can accelerate bacterial growth in seawater. Results show that the net growth of bacteria within a 7-day incubation period was directly 
proportional to the concentration of AOM in seawater. A significant linear correlation $\left(R^{2} \geq 0.98\right)$ was observed between net growth and the concentration of AOM added to seawater during the exponential growth phase (Figure 5b).
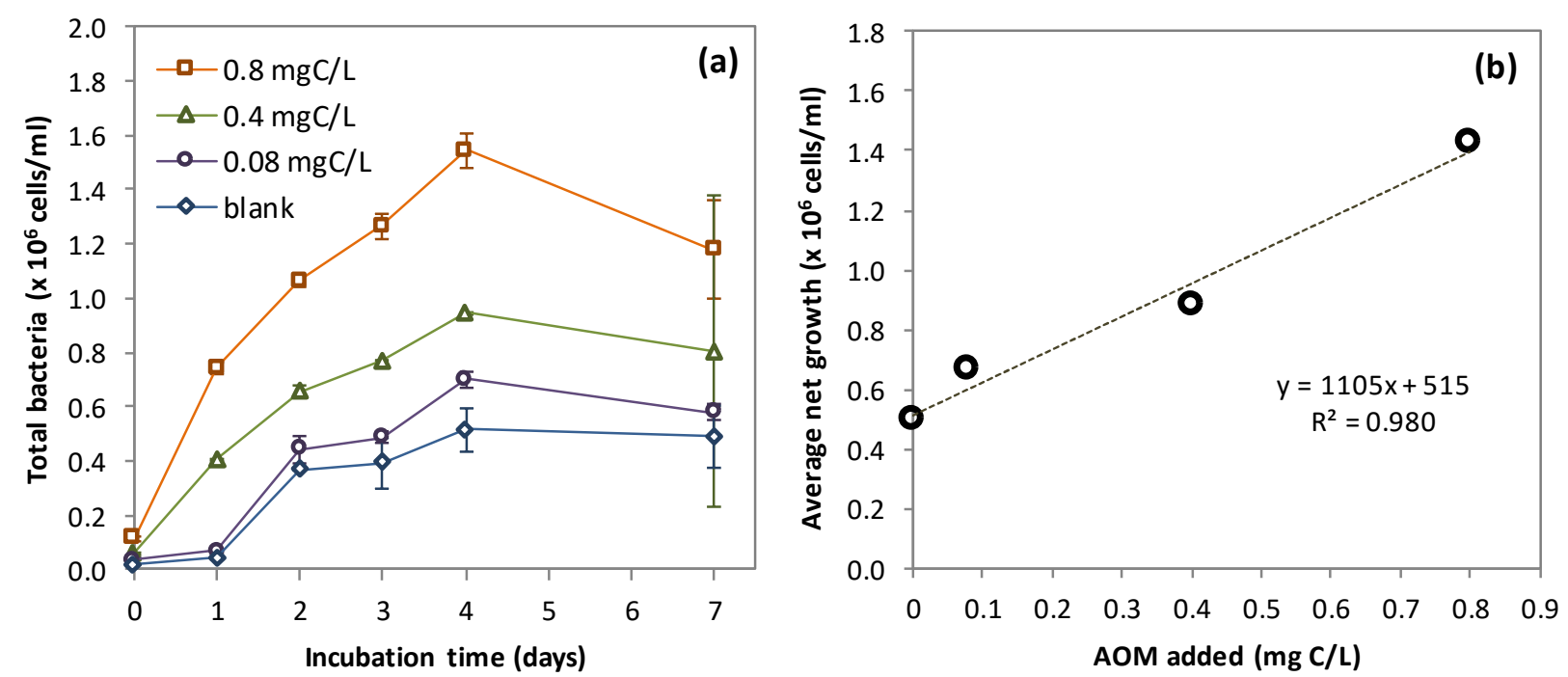

Figure 5. (a) Growth curves of a natural bacterial consortium in batch seawater solutions spiked with different concentrations of AOM. (b) Linear regression between AOM concentration and average net growth at day 4 of the incubation period. Error bars in (a) represent the standard deviation for two separate batch tests.

To investigate which organic fraction in the water was degraded and assimilated by bacteria, LC-OCD analyses were performed for samples collected on Day 0 and Day 4 from the batch with the highest net growth (i.e., seawater spiked with $0.8 \mathrm{mg} \mathrm{C/L} \mathrm{AOM).} \mathrm{For} \mathrm{comparison,} \mathrm{the} \mathrm{samples} \mathrm{of} \mathrm{the} \mathrm{spiked} \mathrm{AOM}$ and $0.2 \mu \mathrm{m}$ pre-filtered natural seawater were also analyzed. As shown in the LC-OCD chromatograms in Figure 6, the solution used in the growth test comprise a mixture of organic substances from AOM solution and natural seawater, with the majority of biopolymers originating from AOM solution while more than half of the low molecular organics were from natural seawater. No apparent change was observed in the chromatogram signature between Day 0 and Day 4 of the incubation period based on the retention times of organic fraction peaks. However, there was a distinguishable change in the 
relative signal response of the peaks, an indication that degradation and/or conversion of some organic constituents in the water occurred due to bacterial activity. Specifically, a decrease in OCD signal was observed for the low molecular weight (LMW) peaks (building blocks, humics, organic acids and neutrals) while an increase in response was observed for the biopolymer peaks. An area integration of the chromatogram peaks per Huber et al. (2011) shows that the total concentration of the LMW fractions were decreased by $88 \mu \mathrm{g} C / \mathrm{L}$, which may account for the organic nutrients assimilated by bacteria. On the other hand, the increase $(5 \mu \mathrm{g} C / L)$ in biopolymer concentration may be attributed to the release of extracellular polymeric substances from bacteria.

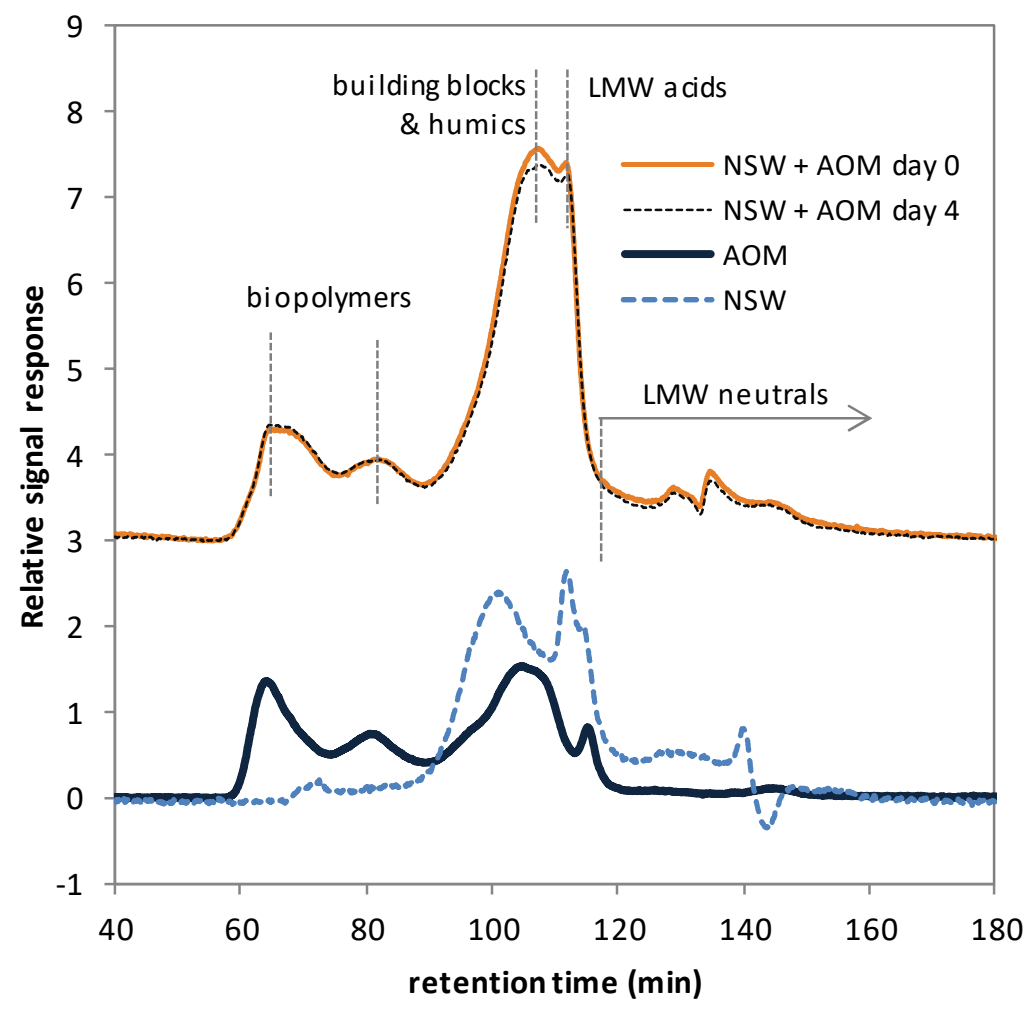

Figure 6. LC-OCD chromatograms for samples collected on Day 0 and Day 4 from a batch containing seawater spiked with $0.8 \mathrm{mg} \mathrm{C} / \mathrm{L}$ of AOM. For reference, the chromatogram of the AOM and $0.2 \mu \mathrm{m}$ prefiltered natural seawater (NSW) are presented. The offset in OCD chromatograms were intentionally made for clarity. 
The water organic carbon concentration decline after four days of incubation may represent the biodegradable fraction of organic matter which is often measured as biodegradable organic carbon (BDOC) or assimilable organic carbon (AOC). For comparison, the value found in the experiment is within the range of seawater AOC concentrations (30-360 $\mu \mathrm{g} \mathrm{Ac-C/L)} \mathrm{reported} \mathrm{by} \mathrm{Weinrich} \mathrm{et} \mathrm{al.} \mathrm{(2011)}$ but lower than the range of seawater BDOC concentrations $(190-290 \mu \mathrm{g} / \mathrm{L})$ reported by de Vittor et al. (2009).

The possible role of AOM in membrane biofouling can be attributed to its ability to support growth of bacteria either as a platform and as a carbon food source. In this context, platform refers to the ability of AOM to absorb and concentrate nutrients from the feed water, so that the attached bacteria can utilize them efficiently and growth is accelerated. The bacterial growth test results illustrate that AOM can indeed increase the capacity of the water to support bacterial growth. However, based on the change of LC-OCD chromatogram at the start and end of the growth tests, the biopolymer fraction was virtually intact while the low molecular weight components were reduced. These may suggest that the biopolymer fraction mainly functioned as a growth platform while part of the low molecular fraction may have served as a nutrient source for the bacteria, at least on the short term considering that the chromatogram comparison was done with only 4 days in between.

Elevated bacterial activity during algal blooms are well documented, especially at the senescent phase of the bloom in which most AOM are released from the cells (Grossart, 1999; Cole, 1982). In natural aquatic systems, AOM component like TEPs can be degraded by bacteria in a matter of hours to several months (Passow, 2002). However, as illustrated in the experiments, high molecular weight AOMs (i.e., biopolymers) may not be readily biodegradable. However, it may eventually be degraded by bacteria when the readily biodegradable dissolved organic nutrients in the water have been depleted. On the 
other hand, essential nutrients can be limited (e.g., phosphate) during the peak of an algal bloom due to uptake by algae. However, when the bloom reaches a decline phase, a significant amount of dead algal cells will disintegrate and release some of these nutrients. Hence, AOM associated biofouling in RO plants may not necessarily occur during the algal bloom period but could be observed well after the termination of the bloom. Further investigations are necessary to verify such scenario.

\subsection{Effect of AOM suspended in the feed water}

The role of $A O M$ and essential nutrients (i.e., $\mathrm{C}: \mathrm{N}: \mathrm{P}$ ) in the feed water on biological fouling in a crossflow membrane system was investigated through experiments with capillary UF membranes. Parallel biofouling experiments were performed to compare cake resistance development and pressure drop increase in the system when fed with solutions comprising different combinations of nutrients and AOM (0.5 $\mathrm{mg} \mathrm{C/L}$ ) as described in Table 1 (tests S1-S4).

As shown in Figure 7, the increase in cake resistance and feed channel pressure drop were not substantially different for the four experiments during the first 8 days of the tests. After Day 8 , an exponential increase of both cake resistance (up to 350\%) and pressure drop (up to 500\%) was recorded for the membrane module fed with water containing both AOM and CNP nutrients. A substantial increase (up to $100 \%$ ) in cake resistance was also observed for the membrane fed with CNP nutrients only, but no significant change in pressure drop was recorded. For membranes fed with AOM only and membranes fed with AOM + NP nutrients, no significant increase in cake resistance and pressure drop was observed. 


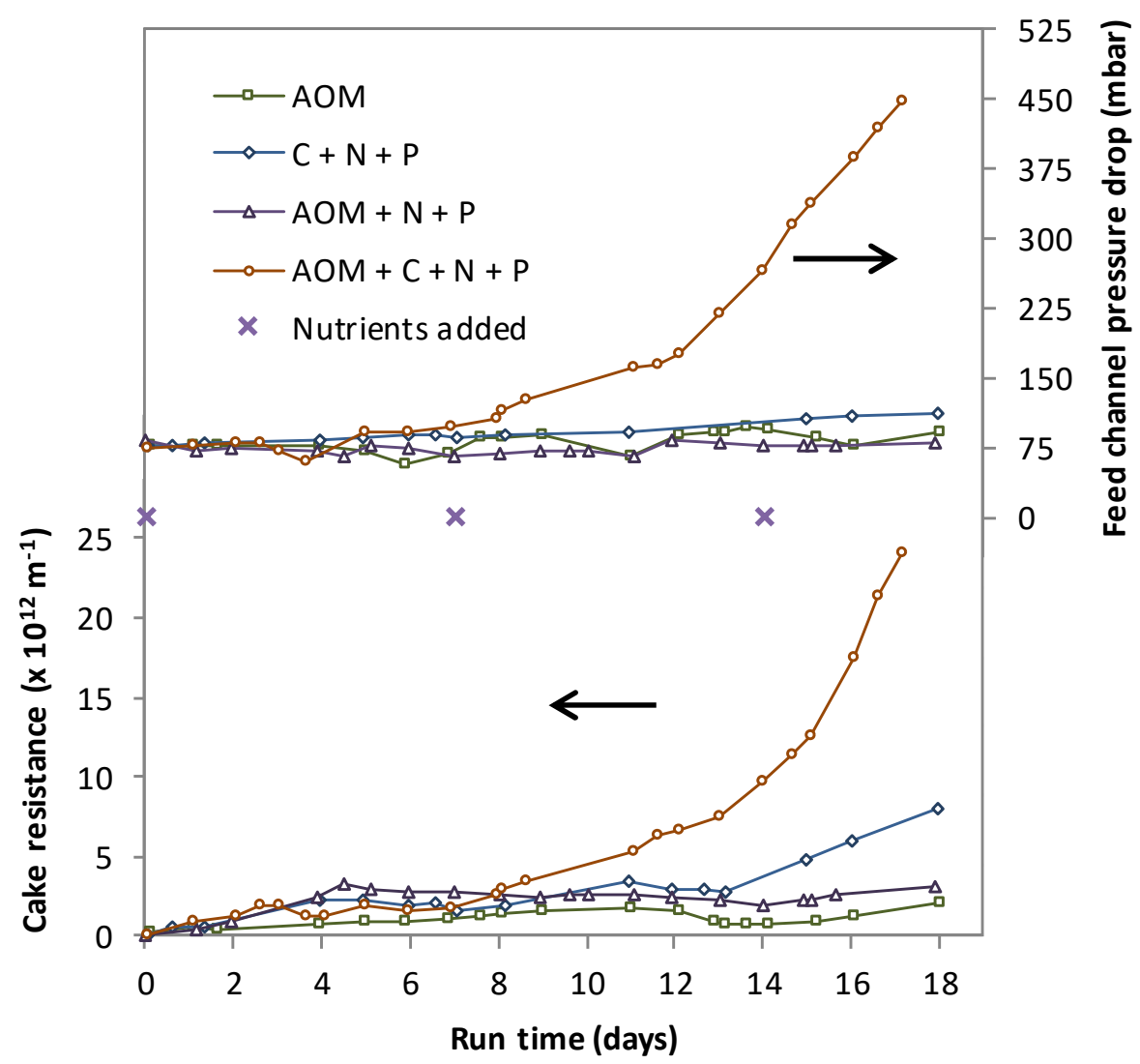

Figure 7. Change in cake resistance and feed channel pressure drop through cross-flow capillary membranes comparing the effect of feed water with different composition. Legend: $A O M=$ algal organic matter $(0.5 \mathrm{mgC} / \mathrm{L}), \mathrm{C}=0.2 \mathrm{mg} / \mathrm{L}$ acetate carbon, $\mathrm{N}=0.04 \mathrm{mg} \mathrm{N} / \mathrm{L}$ nitrate, $\mathrm{P}=0.01 \mathrm{mg} \mathrm{P} / \mathrm{L}$ phosphate.

Overall, the experiments illustrate that AOM suspended in nutrient-rich seawater can substantially accelerate biofouling on the membrane. AOM as such appear not to directly cause severe biofouling on the membranes when at least one of the essential nutrients are limited in the feed water. This may indicate that despite its high organic carbon content, AOM is not may not be an adequate substitute for readily biodegradable organic carbon nutrient in the feed water. Such finding corroborates with the growth test results in which AOM showed to support bacterial growth without showing significant degradation of its components (Section 3.2).

\subsection{Effect of AOM deposited on the membrane}


The two sets of biofouling experiments described in this section were performed to test the hypothesis that $\mathrm{AOM}$ can form a conditioning film on the membrane, facilitate attachment of bacteria and accelerate biofilm development (Bar-Zeev et al., 2012; Berman and Holenberg, 2005). The experiments were performed using capillary and spiral wound membranes, respectively.

\subsubsection{Biofouling in capillary membrane}

Cross-flow experiments using clean and AOM conditioned capillary membranes were performed in two phases as described in Table 1 (tests $\mathrm{C} 5-\mathrm{C} 6$ ). For the first phase (AOM conditioning), Membrane 1 was operated with feed water consisting ASW spiked with $0.8 \mathrm{mgC} / \mathrm{L}$ of $\mathrm{AOM}$, until an increase in hydraulic resistance was observed. In the second phase (biofouling), the feed water was replaced with ASW solution containing CNP nutrients and marine bacteria ( $\sim$ million cells $/ \mathrm{ml}$ of $V$. harveyi). For comparison, a clean membrane (Membrane 2) was operated in parallel with the same feed water (ASW + CNP) and flow settings as Membrane 1 .

The AOM conditioning ( 5 days) on Membrane 1 resulted in apparent increase in total hydraulic resistance and feed channel pressure drop. After the nutrients and marine bacteria were added, an exponential increase in cake resistance immediately followed for both clean and AOM-conditioned membranes (Figure 8). During the biofouling phase, the cake resistance and feed channel pressure drop in the module with AOM-conditioned membranes increased by $5.45 \times 10^{13} \mathrm{~m}^{-1}$ and $80 \mathrm{mbar}$, respectively. In comparison, the cake resistance and feed channel pressure drop in the module with initially clean membrane (Membrane 2 ) only increased by $1.99 \times 10^{13} \mathrm{~m}^{-1}$ and $12 \mathrm{mbar}$, respectively. Overall, the results illustrate that the initial pre-conditioning with AOM in capillary membranes can led to accelerated biofouling development. 

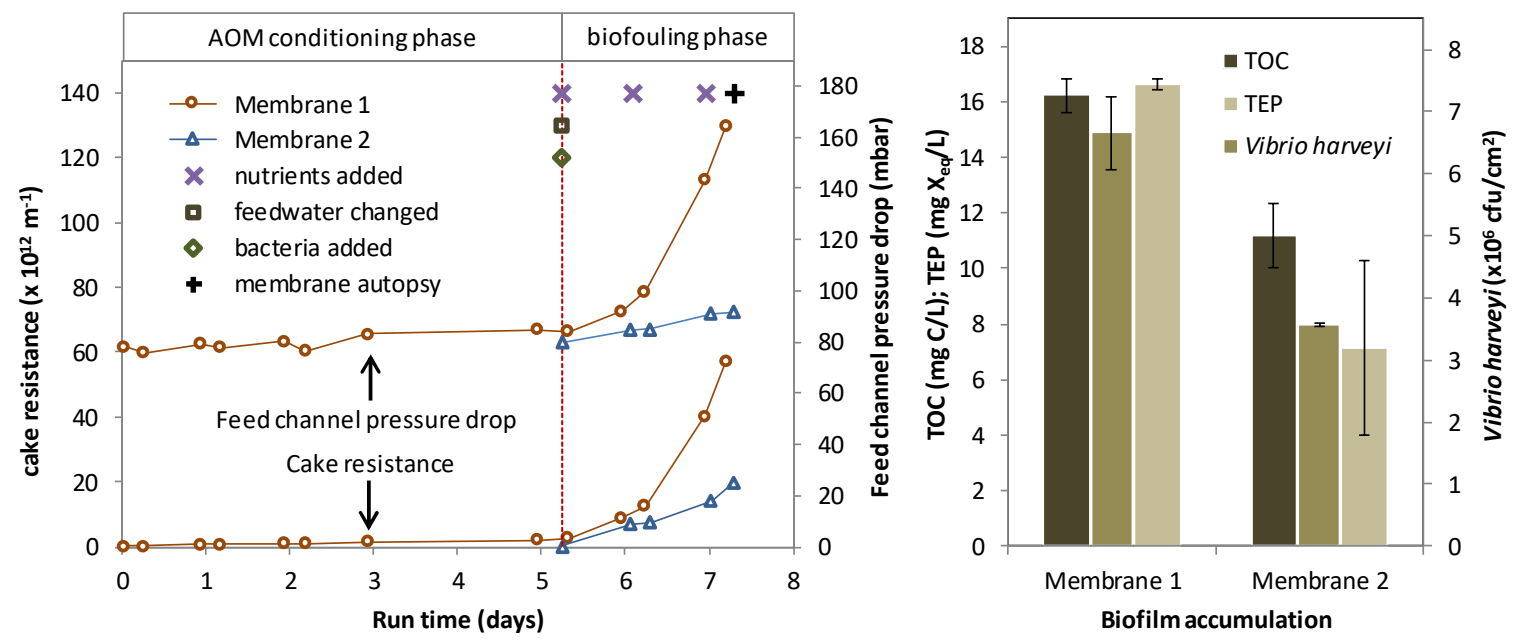

Figure 8. (Left) Progression of biofilm resistance on AOM pre-conditioned (Membrane 1) in comparison with initially clean (Membrane 2) capillary membranes; (Right) Total organic carbon (TOC), transparent exopolymer particles (TEP) and bacterial concentration in the biofilm extracted during membrane autopsy after the biofouling tests.

An autopsy of the fouled capillary membrane modules was performed after the biofouling experiments to measure accumulation of biofilm in terms of TOC, TEP and $V$. harveyi concentrations. All three parameters indicate that biofouling was more severe in the AOM pre-fouled membrane (Figure 8). The concentration of $V$. harveyi bacteria $\left(\sim 6.5 \times 10^{6} \mathrm{cfu} / \mathrm{cm}^{2}\right)$ was within the range of bacterial concentrations reported in biofouled RO membrane modules (Vrouwenvelder et al., 2008). These model bacteria are relatively large (up to $10 \mu \mathrm{m}$ in length) compared to most marine bacteria and has been reported to produce substantial amounts of TEP-like EPS (Bramhachari and Dubey, 2006). Such characteristics may have enabled them to be more effective in forming biofilm on the surface of the membrane.

\subsubsection{Biofouling in spiral wound membrane}

The effect of AOM on biofouling in spiral wound membranes was determined from the changes of feed channel pressure drop and visual observation in MFS flow cells. The experiments were performed in 
three phases (AOM conditioning, bacterial attachment and biofouling) using 4 MFS cells operated under the conditions described in Table 1 (Test S7-S10). For the AOM conditioning phase, ASW spiked with 1 $\mathrm{mg} \mathrm{C/L}$ of AOM was fed and recirculated to 2 MFS cells with clean RO membranes until a significant increase (>20\%) in pressure drop was observed. For the bacterial attachment phase, the feed solution with AOM was discarded and a newly-prepared ASW solution spiked with $V$. harveyi was fed and recirculated through each of MFS cells for about 24 hours. For the biofouling phase, the feed water of MFS 1 and MFS 2 were replenished with ASW solution spiked with fresh CNP nutrients. For comparison, MFS 3 and MFS 4 with clean membranes were simultaneously operated under the same settings as in MFS 1 and 2 but skipping the AOM conditioning phase.

As shown in Figure 9, AOM conditioning in MFS 1 and 2 resulted in 22-24\% increase in pressure drop after three days. Based on visual inspection, there was no discernible accumulation of AOM or biofilm during the AOM pre-fouling phase despite the significant increase in pressure drop, possibly because of the transparent nature of AOM (Villacorte et al., 2015d). The pressure drop further increased by 9-14\% within 24 hours after introducing $V$. harveyi bacteria in the feed water, while no apparent increase was observed for MFS 3 and 4. This may indicate that the marine bacteria deposit more effectively on the AOMconditioned membrane than on the clean membrane. This is consistent with the results of the AFM adhesion test which suggests that EPS coated bacteria will accumulate faster and adhere strongly on membrane surface already covered with AOM.

During the biofouling phase, in which nutrients were spiked in the feed water, biofouling was observed for all 4 MFS cells but the AOM-preconditioned membranes (MFS 1 and 2) showed much higher rates of fouling. The pressure drop in MFS 1 and MFS 2 increased by about $600 \%$ and $250 \%$ within 6 days after nutrients were added in the feed water. In comparison, the membrane not pre-conditioned with AOM 
(MFS 3 and 4) only increased by about $55-110 \%$ for the same period and about $250 \%$ after an extended 14-day period.
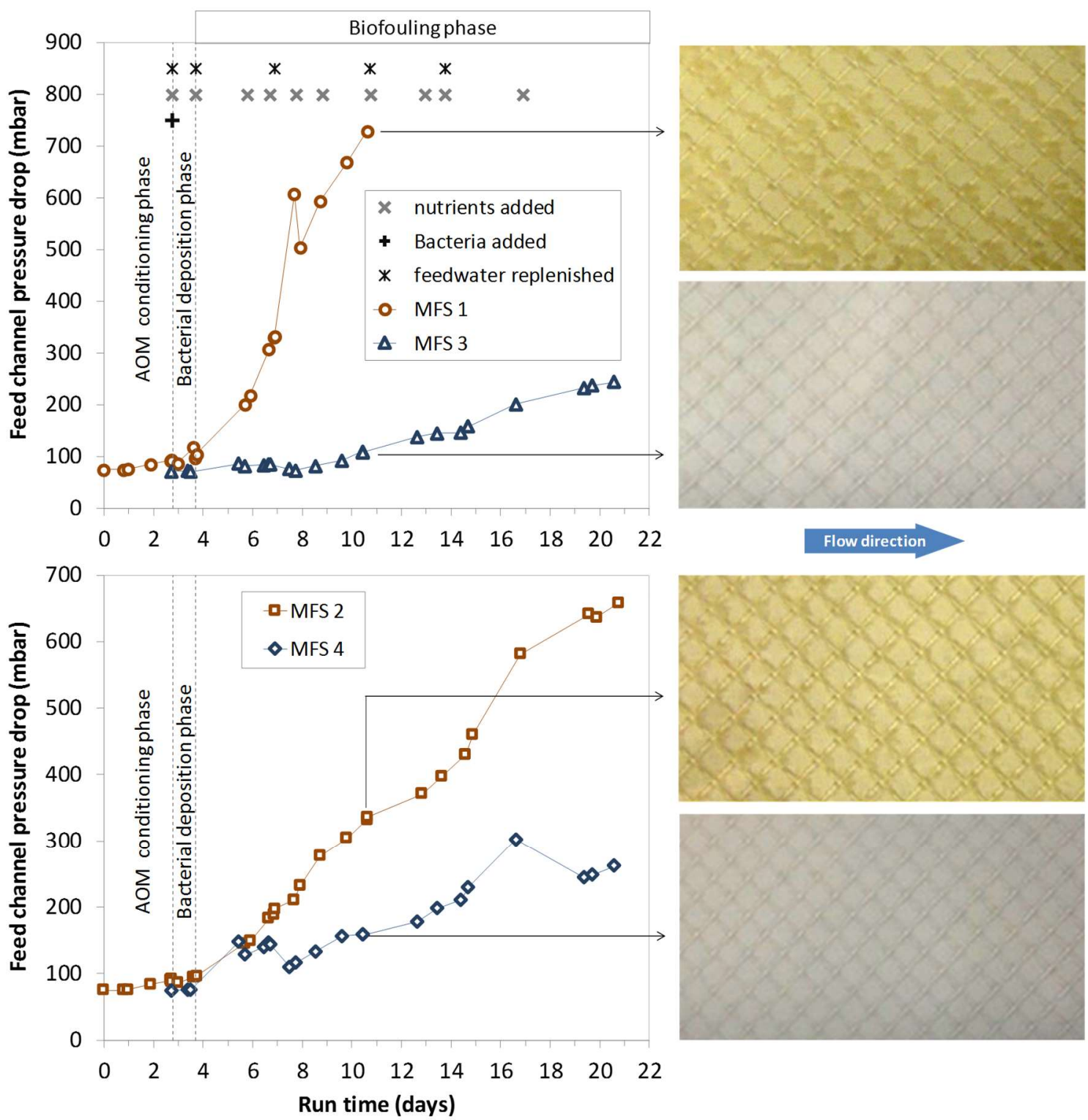

Figure 9. Evolution of pressure drop across the feed channel of spiral wound membranes in MFS cells with (MFS 1 and 2) and without (MFS 3 and 4) AOM pre-conditioning phase. Inset images are photographs taken from the transparent top of the 4 MFS cells during day 10 of the biofouling experiments. 


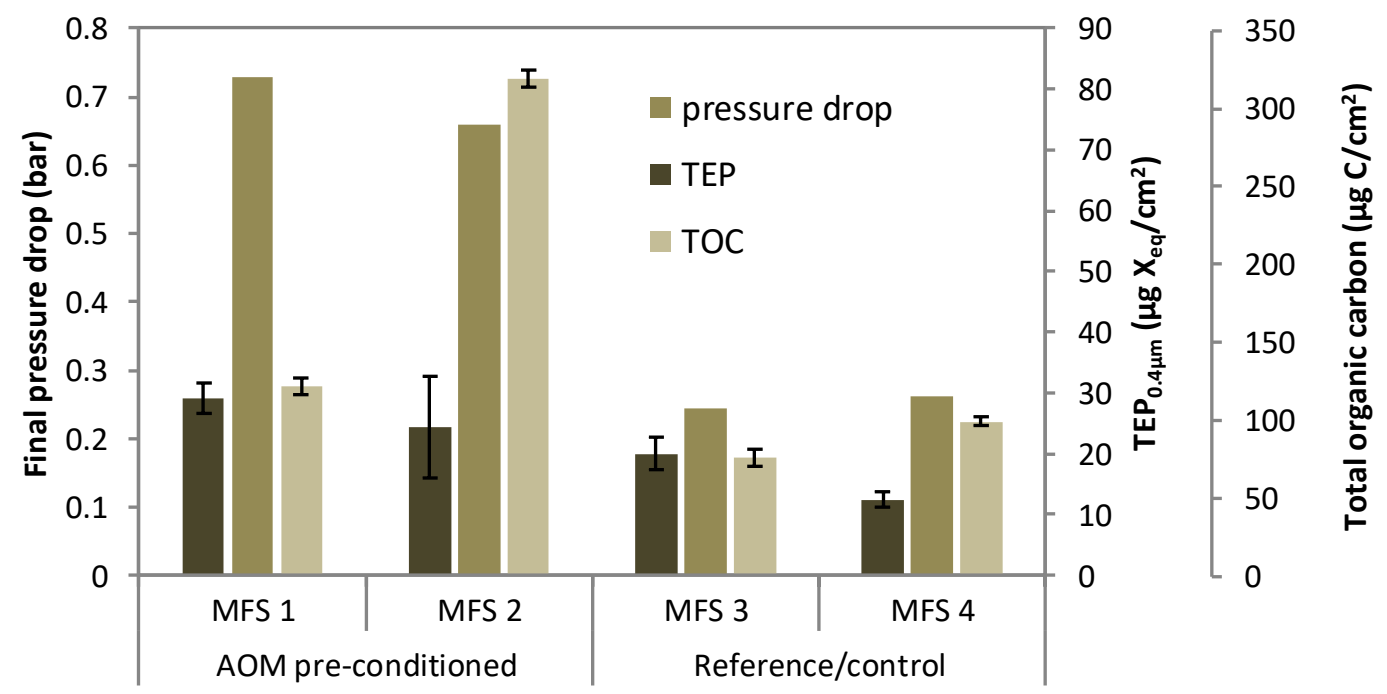

Figure 10. TEP and TOC concentrations in biofilm extracted from membranes and spacers in the MFS at the end of the biofouling experiments in comparison with the feed channel pressure drop. Biofilm extracted on Day 10 from MFS 1 and on Day 20 from MFS 2, 3 and 4.

At the end of the biofouling tests, an accumulation of biofilm on the membrane and spacer preconditioned with AOM was clearly observed, while much less accumulation was visible on the membranes that were not pre-conditioned. The biofilms observed were in a form of streamers and blobs, obstructing up to about $40 \%$ of the feed channel. These were concentrated on the intersections of the spacer mesh distributed along the length of the MFS cell. Such observations are consistent with the experimental and modelling results of Vrouwenvelder et al. (2009; 2010). TOC and TEP analyses of biofilms extracted from 4 MFS cells at the end of biofouling experiments also signifies higher biofilm accumulation on MFS with AOM pre-conditioned membranes than those with initially clean membranes (Figure 10).

Overall, both tests with capillary and spiral wound membranes illustrate that AOM, whether suspended in the feedwater or attached to the surface of the membrane, can facilitate the various processes leading to the onset of biofouling. 


\section{Conclusions}

The results of the study provided quantitative and visual evidence that algal organic matter (AOM) can accelerate the onset of various processes leading to biofouling of spiral wound and capillary membranes, namely by (1) forming a conditioning layer on the membrane, (2) facilitating enhanced bacterial attachment and (3) providing a platform for bacteria to jump-start biofilm development. The specific findings are as follows:

- $\quad$ AFM force measurements reveal that AOM has the propensity to adhere to a membrane surface and will require significant force to be removed from the membrane. An order of magnitude higher energy will be required if the AOM is deposited on a membrane that is already covered with AOM.

- The capacity of seawater to support growth of bacteria showed a positive linear correlation with AOM concentration in the water. This was attributed to the tendency of AOM, specifically TEPs, to absorb and concentrate nutrients from the feed water providing nourishment for bacteria attached to it.

- Accelerated biofouling experiments performed with spiral wound and capillary membranes illustrate that when biodegradable nutrients are not limited in the feed water, a high concentration of AOM - either in the feed water or attached to the membrane - can substantially accelerates biofouling. A substantially lower biofouling rate was observed when the membranes were exposed to feed water spike with only AOM or only nutrients. 


\section{Acknowledgements}

This work was financially supported by IHE Delft Institute for Water Education, Wetsus Centre of Excellence for Sustainable Water Technology and the Water Desalination and Reuse Center at KAUST. We acknowledge the analytical/technical support of Z. Nyambi, M. Gharaibeh E. Spruijt, E.I. Prest and S. Huber. We thank the two anonymous reviewers and L.H. Kim for their constructive feedback and the members of the Wetsus research theme "Biofouling" for fruitful discussions.

\section{References}

Alldredge, A. L., Passow, U., \& Logan, B. E. (1993). The abundance and significance of a class of large, transparent organic particles in the ocean. Deep-Sea Research I, 40, 1131-1140.

Allison, D. G.; Sutherland, I. W. (1987) The role of exopolysaccharides in adhesion of freshwater bacteria. Journal of General Microbiology 133(5), 1319-1327.

Amy, G. (2008) Fundamental understanding of organic matter fouling of membranes, Desalination 231, 44-51.

Araújo, P.A., Van Loosdrecht, M.C.M., Kruithof, J.C., Vrouwenvelder, J.S. (2012). The potential of standard and modified feed spacers for biofouling control. Journal of Membrane Science 403404, 58-70.

Baker, J. S.; Dudley, L. Y. (1998) Biofouling in membrane systems-A review. Desalination 118(1-3), 8189.

Bar-Zeev, E., Passow, U., Romero-Vargas Castrillón, S., Elimelech, M. (2015) Transparent Exopolymer Particles (TEP): From Aquatic Environments and Engineered Systems to Membrane Biofouling. Environ. Sci. Technol. 49 (2), 691-707. 
Bar-Zeev E, Berman-Frank I, Girshevitz O, Berman T. (2012) Revised paradigm of aquatic biofilm formation facilitated by microgel transparent exopolymer particles. PNAS 109(23), 9119-24.

Bar-Zeev, E., Berman-Frank, I., Liberman, B., Rahav, E., Passow, U. and Berman, T. (2009) Transparent exopolymer particles: Potential agents for organic fouling and biofilm formation in desalination and water treatment plants. Desalination \& Water Treatment 3, 136-142.

Berman, T., and Holenberg (2005) M., Don't fall foul of biofilm through high TEP levels. Filtration \& Separation 42(4), 30-32.

Berman, T., R. Mizrahi \& C. G. Dosoretz (2011) Transparent exopolymer particles (TEP): A critical factor in aquatic biofilm initiation and fouling on filtration membranes. Desalination, 276, 184-190.

Bramhachari P.V. and Dubey S.K. (2006) Isolation and characterization of exopolysaccharide produced by Vibrio harveyi strain VB23. Letters in Applied Microbiology 43, 571-577.

Characklis, W. G. (1981) Bioengineering report: Fouling biofilm development: A process analysis. Biotechnology and Bioengineering 23: 1923-1960.

Cole, J. J. (1982). Interactions between bacteria and algae in aquatic ecosystems. Annual Review of Ecology and Systematics 13, 291-314.

de la Torre, T., Lesjean, B., Drews, A., and Kraume, M. (2008) Monitoring of transparent exopolymer particles (TEP) in a membrane bioreactor (MBR) and correlation with other fouling indicators. Water Science and Technology 58 (10), 1903-1909.

De Vittor, C., Larato, C., \& Umani, S. F. (2009). The application of a plug-flow reactor to measure the biodegradable dissolved organic carbon (BDOC) in seawater. Bioresource Technology, 100(23), 5721-5728.

Discart, V., Bilad, M. R., Vandamme, D., Foubert, I., Muylaert, K., \& Vankelecom, I. F. J. (2013). Role of transparent exopolymeric particles in membrane fouling: Chlorella vulgaris broth filtration. Bioresource Technology, 129, 18-25. 
Dow D\&WS (2011) FilmTec ${ }^{\circledR}$ Reverse Osmosis Membranes Technical Manual. Form No. 609-00071-0416.

Flemming, H. C. \& G. Schaule (1988) Biofouling on membranes - A microbiological approach. Desalination, 70, 95-119.

Flemming, H. C. (2002) Biofouling in water systems-cases, causes and countermeasures. Applied Microbiology and Biotechnology 59, 629-640.

Flemming, H.C., Schaule, G., Griebe, T., Schmitt, J., \& Tamachkiarowa, A. (1997) Biofouling - the achilles heel of membrane processes. Desalination, 113(2-3), 215-225.

Frank, B. P., \& Belfort, G. (2003). Polysaccharides and sticky membrane surfaces: Critical ionic effects. Journal of Membrane Science, 212(1-2), 205-212.

Grossart, H.P. (1999). Interactions between marine bacteria and axenic diatoms (cylindrotheca fusiformis, nitzschia laevis, and thalassiosira weissflogii) incubated under various conditions in the lab. Aquatic Microbial Ecology 19(1), 1-11.

Guillard, R.R.L. (1975) Culture of phytoplankton for feeding marine invertebrates. In Smith W.L. and Chanley M.H (Eds.) Culture of Marine Invertebrate Animals. pp 26-60. Plenum Press, New York, USA.

Hammes, F. A., and T. Egli (2005) New method for assimilable organic carbon determination using flowcytometric enumeration and a natural microbial consortium as inoculum. Environ. Sci. Technol. 39, 3289-3294.

Henderson, R.K., Baker, A., Parsons, S.A. and Jefferson, B. (2008) Characterisation of algogenic organic matter extracted from cyanobacteria, green algae and diatoms. Water Research 42, 3435-3445.

Her N., Amy G., Park H.R. and Song M. (2004), Characterizing algogenic organic matter (AOM) and evaluating associated NF membrane fouling, Water Research 38, 1427-1438.

Huber S. A. (2012) Personal communication. 
Huber S. A., Balz A., Abert M. and Pronk W. (2011) Characterisation of aquatic humic and non-humic matter with size-exclusion chromatography - organic carbon detection - organic nitrogen detection (LC-OCD-OND). Water Research 45 (2), 879-885.

Hurwitz, G., Guillen, G. R., \& Hoek, E. M. V. (2010). Probing polyamide membrane surface charge, zeta potential, wettability, and hydrophilicity with contact angle measurements. Journal of Membrane Science, 349(1-2), 349-357.

Hydranautics (2014) Foulants and Cleaning Procedures for composite polyamide RO Membrane Elements. Technical service bulletin TSB107.23.

Jeong S., Kim S.J., Kim L.H., Shin M.S., Vigneswaran S., Vinh Nguyen T. (2013) Foulant analysis of a reverse osmosis membrane used pretreated seawater. J. Membr. Sci. 428, 434-444.

Kennedy, M. D., Muñoz-Tobar, F. P., Amy, G. L. and Schippers, J. C. (2009) Transparent exopolymer particle (TEP) fouling of ultrafiltration membrane systems. Desalination \& Water Treatment 6(13) $169-176$.

Lee H., Park C., Kim H., Park H., Hong S. (2015) Role of transparent exopolymer particles (TEP) in initial bacterial deposition and biofilm formation on reverse osmosis (RO) membrane. Journal of Membrane Science 494, 25-31.

Li Q. and Elimelech M. (2004) Organic Fouling and Chemical Cleaning of Nanofiltration Membranes: Measurements and Mechanisms. Environ. Sci. Technol. 38 (17), 4683-4693.

Li S, Winters H, Villacorte LO, Ekowati Y, Emwas AH, Kennedy MD, Amy GL (2015). Compositional similarities and differences between transparent exopolymer particles (TEPs) from two marine bacteria and two marine algae: significance to surface biofouling. Marine Chemistry 174, 131140.

Li S., Sinha S., Leiknes T., Amy G.L., Ghaffour N. (2016) Evaluation of potential particulate/colloidal TEP foulants on a pilot scale SWRO desalination study. Desalination 393, 127-134. 
Marshall, K. C. (1996) Adhesion as a strategy for access to nutrients, p. 59-87. In M. Fletcher (ed.), Bacterial adhesion: molecular and ecological diversity. Wiley-Liss, New York, NY.

Mosley, L. M., Hunter, K. A., \& Ducker, W. A. (2003). Forces between colloid particles in natural waters. Environmental Science and Technology, 37(15), 3303-3308.

Nguyen, T.; Roddick, F.A.; Fan, L. (2012) Biofouling of Water Treatment Membranes: A Review of the Underlying Causes, Monitoring Techniques and Control Measures. Membranes 2, 804-840.

Passow, U. (2002) Transparent exopolymer particles (TEP) in aquatic environments, Progress In Oceanography 55(3-4), 287-333.

Passow, U. and Alldredge, A. L. (1995) A Dye-Binding Assay for the Spectrophotometric Measurement of Transparent Exopolymer Particles (TEP). Limnology and Oceanography 40(7), 1326-1335.

Passow, U., \& Alldredge, A. L. (1994). Distribution, size, and bacterial colonization of transparent exopolymer particles (TEP) in the ocean. Marine Ecology Progress Series, 113, 185-198.

Pieracci, J., Crivello, J. V., \& Belfort, G. (1999). Photochemical modification of 10kDa polyethersulfone ultrafiltration membranes for reduction of biofouling. Journal of Membrane Science, 156(2), 223-240.

Prest, E.I., Hammes, F., Kötzsch, S., van Loosdrecht, M.C.M, Vrouwenvelder, J.S. (2013) Monitoring microbiological changes in drinking water systems using a fast and reproducible flow cytometric method, Water Research In Press, doi: 10.1016/j.watres.2013.07.051.

Ramus, J. (1977) Alcian Blue: A Quantitative Aqueous Assay for Algal Acid and Sulfated Polysaccharides. Journal of Phycology 13, 345-348.

Ricq, L., Pierre, A., Bayle, S., \& Reggiani, J.C. (1997). Electrokinetic characterization of polyethersulfone UF membranes. Desalination 109(3), 253-261. 
Schurer R., Tabatabai A., Villacorte L., Schippers J.C., Kennedy M.D. (2013) Three years operational experience with ultrafiltration as SWRO pre-treatment during algal bloom. Desalination \& Water Treatmen 51 (4-6), 1034-1042.

SLMB (2012) Determining the total cell count and ratios of high and low nucleic acid content cells in freshwater using flow cytometry. Analysis method 333.1, The Swiss Food Book (Schweizerische Lebensmittelbuch). Federal Office of Public Health, Switzerland.

Spruijt E., van den Berg S.A., Cohen-Stuart M.A., and van der Gucht J. (2012) Direct Measurement of the Strength of Single lonic Bonds between Hydrated Charges. ACS Nano 6 (6), 5297-5303.

Valladares Linares R., Yangali-Quintanilla V., Li Z., Amy G. (2012) NOM and TEP fouling of a forward osmosis (FO) membrane: Foulant identification and cleaning. Journal of Membrane Science 421$422,217-224$.

Van Nevel, S., Hennebel, T., De Beuf, K., Du Laing, G., Verstraete, W., \& Boon, N. (2012). Transparent exopolymer particle removal in different drinking water production centers. Water Research, 46(11), 3603-3611.

Villacorte L.O (2014) Algal blooms and membrane-based desalination technology, ISBN 978-1-13802626-1, CRC Press, Balkema, Leiden.

Villacorte LO, Tabatabai SAA, Dhakal N, Amy G, Schippers JC, Kennedy MD (2015a) Algal blooms: an emerging threat to seawater reverse osmosis desalination. Desalination and Water Treatment 55 (10), 2601-2611

Villacorte LO, Tabatabai SAA, Anderson DM, Amy GL, Schippers JC, Kennedy MD (2015b) Seawater reverse osmosis desalination and (harmful) algal blooms, Desalination 360, 61-80.

Villacorte LO, Ekowati Y, Winters H, Amy G, Schippers JC, Kennedy MD (2015c) MF/UF rejection and fouling potential of algal organic matter from bloom-forming marine and freshwater algae. Desalination 367, 1-10. 
Villacorte LO, Ekowati Y, Neu TR, Kleijn JM, Winters H, Amy G, Kennedy MD (2015d) Characterisation of algal organic matter produced by bloom-forming marine and freshwater algae. Water Research 73, 216-230.

Villacorte LO, Ekowati Y, Calix-Ponce HN, Schippers JC, Amy GL, Kennedy MD (2015e) Improved method for measuring transparent exopolymer particles (TEP) and their precursors in fresh and saline water. Water research 70, 300-312

Villacorte, L. O., Kennedy, M. D., Amy, G. L., and Schippers, J. C. (2009) The fate of Transparent Exopolymer Particles (TEP) in integrated membrane systems: Removal through pretreatment processes and deposition on reverse osmosis membranes. Water Research 43 (20), 5039-5052.

Villacorte, L. O., Schurer, R., Kennedy, M., Amy, G. and Schippers, J.C. (2010) Removal and deposition of Transparent Exopolymer Particles (TEP) in seawater UF-RO system. IDA Journal 2 (1), 45-55.

Villacorte, L.O., Ekowati, Y., Winters, H., Amy, G.L., Schippers, J.C. and Kennedy, M.D. (2013) Characterisation of transparent exopolymer particles (TEP) produced during algal bloom: a membrane treatment perspective. Desalination \& Water Treatment 51 (4-6), 1021-1033.

Vrouwenvelder, H.S., Van Paassen, J.A.M., Folmer, H.C., Hofman, J.A.M.H., Nederlof, M.M., Van der Kooij, D. (1998). Biofouling of membranes for drinking water production. Desalination 118, (1-3), $157-166$.

Vrouwenvelder, J.S., Hinrichs, C., Van der Meer, W.G.J., Van Loosdrecht, M.C.M., Kruithof, J.C. (2009). Pressure drop increase by biofilm accumulation in spiral wound RO and NF membrane systems: Role of substrate concentration, flow velocity, substrate load and flow direction. Biofouling 25:543-555.

Vrouwenvelder, J.S., Manolarakis, S.A., van der Hoek, J.P., van Paassen, J.A.M., Van der Meer, W.G.J., Van Agtmaal, J.M.C., Prummel, H.D.M., Kruithof, J.C., Van Loosdrecht, M.C.M. (2008) 
Quantitative Biofouling Diagnosis in Full Scale Nanofiltration and Reverse Osmosis Installations. Water Research 42: 4856-4868.

Vrouwenvelder, J.S., Picioreanu, C., Kruithof, J.C., Van Loosdrecht, M.C.M. (2010) Biofouling in spiral wound membrane systems: Three-dimensional numerical model based evaluation of experimental data. Journal of Membrane Science 346, 71-85.

Vrouwenvelder, J.S., Van Paassen, J.A.M., Wessels, L.P., Van Dam, A.F., Bakker, S.M. 2006. The membrane fouling simulator: A practical tool for fouling prediction and control. Journal of Membrane Science 281: 316-324.

Vrouwenvelder, J.S., Graf von der Schulenburg, D.A., Kruithof, J.C., Johns, M.L., van Loosdrecht, M.C.M. (2009). Biofouling of spiral wound nanofiltration and reverse osmosis membranes: A feed spacer problem. Water Research 43, (3), 583-594.

Weinrich L.A., Schneider O.D. and LeChevallier M.W. (2011) Bioluminescence-Based Method for Measuring Assimilable Organic Carbon in Pretreatment Water for Reverse Osmosis Membrane Desalination Appl. Environ. Microbiol 77 ( 3), 1148-1150.

Winters H. and Isquith I. R. (1979). In-plant microfouling in desalination. Desalination, 30(1), 387-399. Winters, H., Isquith, I., Arthur, W. A., \& Mindler, A. (1983). Control of biological fouling in seawater reverse osmosis desalination. Desalination, 47(1-3), 233-238.

Yamamura, H., Kimura, K., Okajima, T., Tokumoto, H., \& Watanabe, Y. (2008). Affinity of functional groups for membrane surfaces: Implications for physically irreversible fouling. Environmental Science and Technology, 42(14), 5310-5315. 